International Journal of Instruction e-ISSN: 1308-1470 • www.e-iji.net
July $2018 \bullet$ Vol.11, No.3

p-ISSN: 1694-609X

pp. 153-162

Received: 10/11/2017

Revision: 01/03/2018

Accepted: 07/03/2018

\title{
Learning Process of Decimals through the Base Ten Strips at the Fifth Grade
}

\author{
Ari Puspita Rahayu \\ Student. Sriwijaya University, Indonesia,puspitarahayuari@yahoo.com \\ Ratu Ilma Indra Putri \\ Prof., Corresponding author.Sriwijaya University, Indonesia, ratu.ilma@yahoo.com
}

\begin{abstract}
This research aims to produce a learning trajectory that can assist students in studying decimals. The method used in this research is design research with the initial stage at preparing for an experiment, the second stage of the design experiment and the final stage of retrospective analysis. The learning approach used is Indonesian Realistic Mathematics Education (PMRI). Subjects in this research are students of the fifth grade of Elementary School 121 Palembang, Indonesia. Data collection is done through student activity of observation, video recording of events in class, the collection of student work, the collection of the test result of student and student interview. The collected data were then analyzed retrospectively with the results indicating that the learning path obtained can help the students in studying decimals. The learning trajectory includes recognizing the use of decimals in everyday life, recognizing the base ten strips, understanding the value of decimal places through the activity of populating the place value table, showing the value of the decimal places through the activity of arranging the base strip 10, representing the decimal number to the image through the activity Draw base ten strips and use base ten strips-image to complete decimals operation.
\end{abstract}

Keywords: learning trajectory, pmri, decimals, base ten strips, learning process, learning

\section{INTRODUCTION}

Decimal is an important topic in mathematics learning. As mentioned by Behr \& Post (1992) "decimals are yet another important interpretation of the rational number and are very useful in a wide variety of settings. Measurement using the metric system, percent, and money are three of the more important ones ". Based on Graduate Competency Standard (SKL) that must be achieved by students for mathematics subjects based on Permendiknas No. 23 of 2006 (BSNP, 2016) is to understand the concept of integers and fractions, counting operations and their properties, and use them in solving problems of daily life.

Citation: Rahayu, A. P., \& Putri, R. I. I. (2018). Learning Process of Decimals through the Base Ten Strips at the Fifth Grade. International Journal of Instruction, 11(3), 153-162. https://doi.org/10.12973/iji.2018.11311a 
In Elementary School, decimal numbers are still difficult as stated by Galen, Feijs, Figueiredo, Gravemeijer, Herpen, \&Keijzer (2008) in his book mentions that "the fact that the topics-fractions, percentages, decimals, and ratio are some of the Most difficult parts of the primary school curriculum." Also explained by Sembiring et al. (2008), "the teaching and learning of fractions and decimal numbers have been problematic in mathematics education in many countries, especially in primary schools. It is well known that many students struggle to carry out the simple calculation involving fractions ". It has been investigated by Standiford, Klein, \&Tatsuoka (1982) states that,

"The student justifies the numbers along the right hand side and does not align the decimal points. For example, 3,29-1,5 becomes:

$$
\begin{aligned}
& 3,29 \\
& \frac{1,5-}{314} \text { (without decimal point). }
\end{aligned}
$$

The decimal point may be placed corresponding to either addend or, in rare cases, in both positions. Occasionally the student will omit the deimal point. Student may also use the "multiplication rule" for placing the decimal point".

Being described that, the problem of decimal reduction, among other things, the student subtracts down by writing the right number, then puts the semicolon out of sync. Next, the students remove the comma, and also the students use "multiplication rules" to place the comma. According to the National Math Science Initiative (2013), some common mistakes in the concept of decimal number learning include:

(1) Decimals and fractions are often thought of as two separate skills and are taught as such. In fact, decimal numbers are simply another way of writing fractions. Both notations have value, and students should understand how the two are related (2) Knowing decimal place value names does not mean students have conceptual understanding of decimal (3) When comparing and ordering decimals, students often think that 0.19 is greater than 0.2 because they are misapplying what they know about whole number place value to decimal place value.

Based on the statement, it can be seen that students do not understand the relationship between fractions and decimal numbers also students do not understand the concept of place value so that the impact when students compare and sort their decimal numbers assume that 0.19 more than 0.2 due to errors in applying the place value of integers to a decimal number. The difficulty in understanding the place value will affect students' understanding of the operation of the decimal number count, especially the countdown operation of the decimal number that will be discussed in this research.

The problems that occur in the completion of these decimal reduction operations can be overcome with a context known in everyday life. According to Irwin (2001) that students who work on the problem of decimal numbers with the familiar context of the day-to-day, his knowledge is significantly increased compared to students who work on the problem of non-contextual decimal numbers. One of the known contexts of students is measurement. The measurement is "process of experimentally obtaining one or more quantity values that can reasonably be attributed to a quantity" (BiPM et al., 2008). The 
measurements can be used in learning mathematics that connects between mathematical concepts, and the daily experience of students is the emphasis on learning using the approach of Indonesian Realistic Mathematics Education (PMRI). PMRI is an approach adopted from an approach developed by Hans Freudenthal in the Netherlands in 1971 known as Realistic Mathematics Education (RME). PMRI emerged as a special method for learning mathematics (Sembiring, 2010). Since 2001, PMRI became one of the innovations in learning mathematics developed in Indonesia (Zulkardi\&Putri, 2010). Putri (2011) also mentioned that PMRI could lead students in understanding the concept of mathematics by constructing through previous knowledge with the daily or "real" situation. Retnawati et al., (2017) argues that "the learning activities can be conveyed to the real context, providing them with various exercises with big numbers and no integers, habituating them to solve contextual tests Items presented in the form of figures and narratives texts, and habituating them to the test of items through several steps of completion instead of operating the steps directly through basic concepts. It is similar to the PMRI is a strategy that can be used to motivate students to learn mathematics by bringing mathematics into the world of students. The student's life situation is not only limited by what is real to the students' views, but also all imaginable students can be reached by his imagination (Putri, 2013).

In PMRI approach "real" situation requires representation of tool that can support stages of learning. In line with the statement above, GraveMeijer K. (1994) states that "the self-developed models play in bridging gaps between informal knowledge and formal mathematics. It means that students develop models for solving problems. At first, a model is a model of a situation that is familiar to the student. By process of generalizing and formalizing, the model eventually becomes an entity on its own: It is possible that it is used as a model for mathematical reasoning. In other words, the developed model should not only be a model of a "real" situation or context known in everyday life but must also be a model to represent a mathematical solution. Strip base 10 is one of the most useful manipulative materials in the early stages to teach place values and decimal number operations (CBMS, 2012). This is in line with the opinion of Mistutik (2009), the use of decimal point blocks or strip base ten can make learning fun. Also, teachers must have high creativity in teaching math so that students can understand learning well. As explained by Alkharusi, et al. (2017) that "examining self-efficacy of mathematics teachers is important for enhancing student mathematics self-efficacy and academic achievement."

Various researchers on PMRI have been done such as; Pramudiani et al. (2011) using PMRI approach can provoke students' thinking to the idea of using the number line in decimal number learning. Furthermore (Afriansyah, 2013) examines the topic of operation of the sum of decimal numbers finding that the activities that have been created and applied can help the students in understanding the value concepts of decimal places and can lead students from contextual situations to formal situations. Then Nursyahidah et al. (2013) examine the sum of integers using PMRI approaches it can help in describing students' understanding of the concept of summing numbers up to 20. So it can be said that the implementation of mathematics learning using PMRI approach can bring social norms in the classroom, this corresponds to Putri, Dolk, Zulkardi 
(2015) states that teachers have been aware that they have been using some activities that include social norms in the classroom such as encouraging students to ask questions and argue.

This study aims to analyze students' trajectories in decimal number learning using base ten strips in the fifth grade. Base ten strips are used as a tool to help students understand the value of place and the concept of decimal number reduction operations. In this study, researchers used base ten strips made of cardboard made by the researchers as a tool to assist in the learning process.

PMRI principles include progressive guidance and mathematical discovery, didactic phenomena and self-developed models. Wijaya (2012) explains the characteristics of PMRI there is five namely the use of context, the use of models for progressive mathematization, utilization of student construction results, interactivity and the linkage between some parts of the learning materials.

There are four levels in the PMRI according to Gravemeijer: first, at situational levels where these levels are situational knowledge and strategies used in the real context. In this study, researchers used a measurement context with the aim to support student learning about place values in the problem of subtraction operation on decimal. Second, the referential level in which the model and strategy refer to the situation described by the existing problem. A useful discussion can contribute to bridging students from a situational level to a referential level. At this level, students are expected to recognize the base strip form 10 and also recognize the place value of decimal number so that it can be used in subtraction operation on decimal. It helps students to represent their thinking to describe the model of the situation. Third, the general level where the mathematical focus on student strategy in solving the problem dominates the reference to the context. Because students already know the media bade ten strips and they can use it on subtraction, we expect that they use base ten strips to support their reasoning in solving decimal number problems. And fourth, the formal level plays where students work with conventional and notation. At this level, students move from a general situation to a formal mathematical notation by writing numbers using arithmetic methods or by drawing a base strip model 10 in solving subtraction operation on the decimal problem.

\section{METHOD}

\section{Subject of the Reserach}

The study involved 36 students of fifth grade of Elementary School 121 Palembang, Indonesia. And a teacher who acted as model teacher. Design research is used as a method in this study with the aim to prove theories of learning and develop Local Instructional Theory (LIT) with the cooperation of researchers and teachers to improve the quality of learning (Gravemejer\& Cobb, 2006). Gravemeijer\& Cobb (2006) define three phases in design research, among others: (1) preparing for the experiment, (2) the design experiment and (3) retrospective analysis. 
The first stage, preparing the experiment. The researcher conducts literature study through information gathering by conducting the study on an instructional material of decimal reduction operation, PMRI, National Curriculum, and design research as the first step in preparing the alleged early strategy of students in the learning process. Afterwards, the researcher discussed with the classroom teacher about the classroom situation and situation, the research equipment, selected the observer, adjusted the schedule and how the research was conducted with the teacher. Also, researchers also examine the initial ability of students by way of interviewing with some students to be informed about the extent to which students' understanding related to learning prerequisite materials. The results are used by researchers as an ingredient in designing activities for students and poured in the alleged learning trajectory or Hypothetical Learning Trajectory (HLT). Furthermore, Simon (1995) describes HLT as follows:

The hypothetical learning trajectory in made up of three components: the learning goal which defines the direction, the learning activities, and the hypothetical learning process. A prediction of how the students' thinking and understanding will evolve will evolve in the context of the learning activities.

Based on the above statement it is known that HLT consists of learning objectives, learning activities, and hypotheses of the learning process. HLT is used to look at the relationship between the initial conjectures that have been made with the actual data obtained in the field. HLT is dynamic so that they can be adapted to the student's reactions during the learning process.

The second stage, the design experiment consists of two cycles namely pilot experiment and teaching experiment. In this stage, the researcher acts as a model teacher. There are six students selected based on the level of ability that is two high ability, two medium ability, and two low ability. The results from the pilot experiment were used to revise the initial version of HLT for one class participating in teaching experiment. In teaching experiment, 36 students from elementary school 121 Palembang Indonesia involved in this lesson. Students are given learning by their teachers as model teachers (teachers), and the author acts as an observer when learning takes place.

The third stage, retrospective analysis (retrospective analysis). Data obtained from cycle two were analyzed to develop designs on subsequent learning activities. HLT compared with actual student learning activities or actual learning trajectory to answer the research problem formulation. The purpose of retrospective analysis, in general, is to develop the Local Instructional theory (LIT).

\section{Technique of Collecting the Data}

Data collection is done through observation by recording classroom events and student group work evidenced by the video. The designated HLT is then compared to the actual student's trajectory path during the learning for retrospective analysis, students learning or not from the activity that has been designed.

\section{Technique of Analysis the Data}

Data analysis is done by the researcher along with the supervisor to improve the validity and reliability. Validity is useful to see the quality of a set of data that influences the 
conclusion of the research. Reliability is illustrated by a clear description of the data collected so that conclusions can be drawn.

\section{FINDINGS}

This lesson is designed to produce a decimal point learning path using the PMRI approach and find out the role of base ten strip in helping students understand the completion of subtraction operation on decimal. The following teaching experiment results in the second cycle involving 36 students.

The first activity, intended for students to recognize the use of decimal numbers in everyday life and can understand the place value of decimal. The initial phase of the exploration context. At first, students are given the opportunity to recognize the use of decimal numbers in everyday life then students fill in the questions. From the result of the student's answer indicates that the student has been able to write down the example of the decimal number found in everyday life. Students are then asked to remember the base ten strip as an in-depth understanding of the place value of decimal. The results are consistent with the researchers' assumption that students recognize the base ten strip is only one thing, but there is also one who can remember two kinds of base ten strip display well.

After it is enough to remember the strip base 10, students are asked to read the second stage of filling the table. The process of filling the table can be seen in Figure 1.

Figure 1 . The process of filling in the table by students

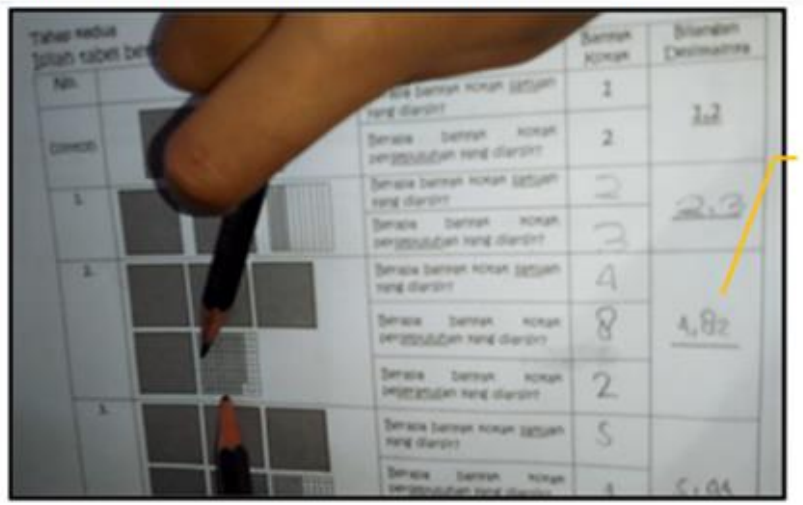

Students answer 4,82

which should be 4,73

In Figure 1, the students calculate the box with the value of the place of a hundred, a decimal and unit. Based on Figure 1 it is seen that the student can recognize the place value but has not been able to understand the place value of tenth and hundredth accurately.

Furthermore, students hone the ability of place value. Students are asked to fill the table with the aim of sharpening the ability to understand place value. The student work can be seen in figure 2 below. 
Figure 2. The process of filling in the table by students for futher problems

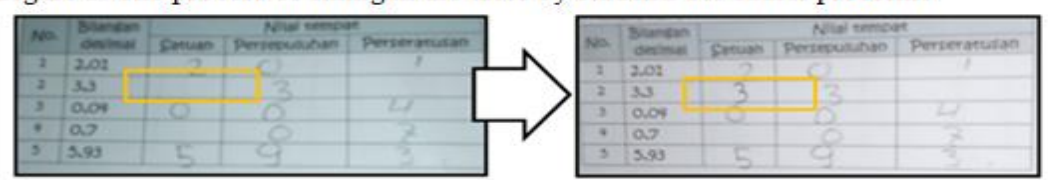

Based on Figure 2 it can be seen that the student has been able to put the exact value well, even though it begins with an error forgetting to write the first number in the unit place value. Students have been able to realize mistakes; it can be concluded that the learning process in understanding the place value works well.

The second activity, the students are required to carry out measurement activities with the primary goal of having students use the base ten strip. The first step, each group measures three objects including the eraser width, the length of the pencil and the thickness of the book. This is so that students can learn decimal numbers with a single digit behind the comma. Furthermore, after the measurement results obtained, students arrange base ten strip which is still a carton to show the value of the place. Then end by drawing the base ten strips. The process of second activity can be seen in figure 3 below.

Figure 3 . The students process measure object to draw a decimal magnitude

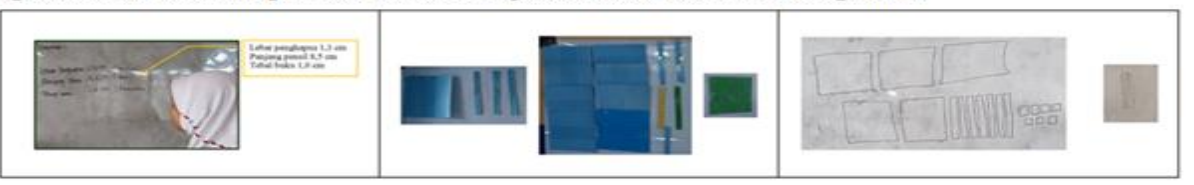

From Figure 3 it can be seen that the students have been able to follow the process of writing the result of measuring objects, arranging the base strip 10 and changing the arrangement of the strip into the image of the decimal representation. Figure 5 presents the activity process two from start to finish.

The third activity, students are given contextual problems related to subtraction operation on decimal. Students are asked to work on questions related to decimal numbers. Results of student work can be seen in figure 6 .

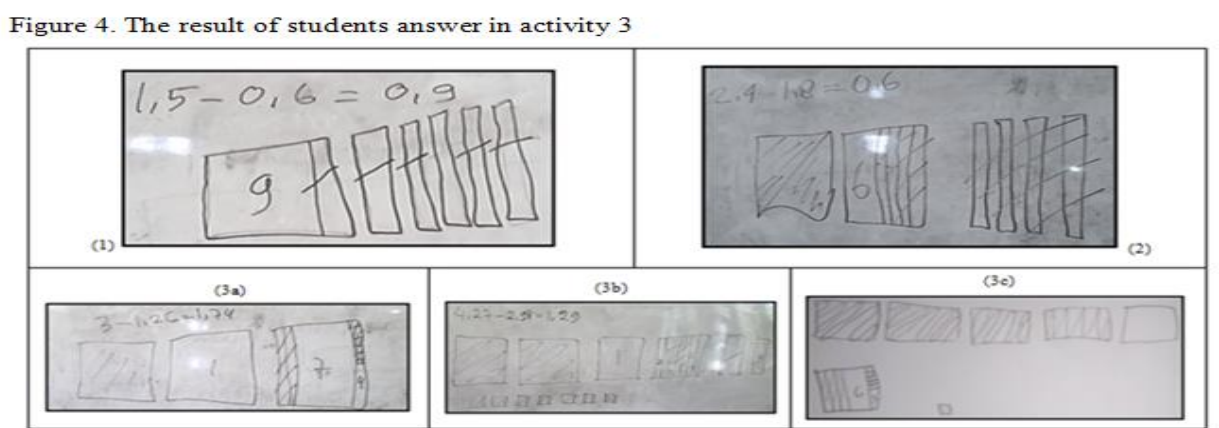

Based on Figure 4 it can be seen that students can complete subtraction operation on decimal using the base ten strip. Students use the concept of subtraction, i.e., write large 
numbers then taken (shaded) as much as deducted. It appears that students are not using short-forming methods. Figure 4 presents the results of students' answers from questions 1 through 3.

The first, second and third activities concluded can help students understand the concept of subtraction operation on decimal. It is by the opinion of the National Math + Science Initiative (2013) that "students use what they know about fractions to begin their exploration of decimals. By connecting fractions, the student will build a deeper understanding of decimals. They explore decimals using base ten blocks and 10x10 grids ". Through the use of the base ten strips in student, activity is given the experience of exporting decimal numbers to achieve an understanding of subtraction operation on decimal.

\section{DISCUSSION}

Based on the results of retrospective analysis on the second cycle (teaching experiment), there are three activities about decimal as follow. (1) Students able to know about using of the decimal number in daily life and understand about place value of the decimal number; (2) through measurement activity, students can use base ten strips in decimal number; (3) students are given contextual problem about decimal subtraction operation.The learning is by HLT designed, and it can be concluded that the students have understood the concept of decimal subtraction operation through a series of activities that have been done using the situation of using base ten strips.

This study also reflects three PMRI principles in the learning process as revealed by Zulkardi \& Putri (2010) namely guided reinvention and progressive mathematizing, didactical phenomenology and self-developed models. Based on the guided reinvention principle, students in the learning process of decimal numbers are given the opportunity to experience the same method as when mathematics was discovered through teacher guidance using a base ten strips as an object that represents the value of a decimal place number.

The second principle is didactical phenomenology. It states that analysis is done on mathematical concepts. Then, it is associated with other an interesting phenomena. The challenge in this principle is the base ten strips appliances as a phenomenon in learning the concept of the place value of decimal.

The third principle is self-developed models. It bridges the students from informal to formal mathematical situations. It can be seen when students do the filling of a table in the form of a base ten strips-image in determining the decimal number. That is followed by modeling that using the way of arranging the base ten strips. In understanding the concept of subtraction operation on decimal utilizing the image stripping base ten represents the student activeness in the learning.

\section{Acknowledgement}

The authors would like to thank Dr. Darmawijoyo has guided the thesis writing so that it can continue to be a published article. Thank you for being a proofreader, writing advisor and suggesting many valuable international journals references to this article. 


\section{CONCLUSION}

Based on the results of research and discussion, it can be concluded that the learning trajectory obtained that consisted of three activities as follow. First, students understand place value of the decimal number using the base ten strips. Second, students' understanding of the decimal number develops the second stage of composing Base Ten Strips according to the value of place then draw it. Finally, students are given contextual questions related to subtraction operation on decimal. Also, the results showed that the use of base ten strips could help students understand about decimal numbers.

\section{REFERENCES}

Afriansyah, E. A. (2013). Design Research: Konsep Nilai Tempat pada operasi Penjumlahan Bilangan Desimal di Kelas V Sekolah Dasar. Jurnal Pendidikan Matematika , 7 (2), 13-23.

Alkharusi, H., Aldhafri, S., Al-Hosni, K., Al-Busaidi, S., Al-Karusi, B., Ambusaidi, A., et al. (2017). Development and Validation of a Scale for Measuring Mathematics Teaching Self-Efficacy for Teachers in the Sultanate of Oman. International Journal of Instruction , 10 (3), 143-158.

Behr, M. J., \& Post, T. R. (1992). Teaching Rational Number and Decimal Concepts. Teaching mathematics in grades K-8: Research-based methods , 201-248.

BiPM, I. E., IFCC, I., ISO, I., \& IUPAP, O. (2008). International Vocabulary of Metrology-Basic and General Concepts and Associated Terms, 2008. JCGM, 200, 99-12.

BSNP. (2016). Standar Nasional; Standar Kompetensi Lulusan. Retrieved June 30, 2016, from BSNP Indonesia: http://bsnp-indonesia.org/?page id=63

CBMS. (2012). The Mathematical education of teachers II (Vol. 17). United States of America: American Mathematical Society.

Galen, F. v., Feijs, E., Figueiredo, N., Gravemeijer, K., Herpen, E. v., \& Keijzer, R. (2008). Fractions, Percentages, Decimals and Proportions; A LEARNING-TEACHING TRAJECTORY FOR. Netherlands: Sense Publishers.

Gravemeijer, K. (1994). Developing Realistic Mathematics Education. CD-Beta-Press.

Gravemeijer, K., \& Cobb, P. (2006). Design research from a learning design perspective. In J. V. Akker, K. Gravemeijer, S. McKenny, \& N. Nieveen, Educational Design Research (pp. 17-51). London and New York: Routledge Taylor \& Francis Group.

Mistutik, S. M. (2009). Meningkatkan Kemampuan Pemahaman Konsep Pecahan Desimal Melalui Penggunaan Blok Desimal Siswa Kelas V SDN Winongan Lor II. Malang: Perpustakaan Digital Universitas Negeri Malang.

National Math + Science Initiative. (2013). Elementary Math. United States: Creative Commons Attribution NonCommercial-NoDerivs.

Nursyahidah, F., Putri, R. I., \& Somakim. (2013). Supporting First Grade Students' Understanding of Addition Up to 20 Using Traditional Game. IndoMS-JME , 4 (2), 212-223. 
Pramudiani, P., Zulkardi, Hartono, Y., \& Amerom, B. v. (2011). A Concrete Situation For Learning Decimals. IndoMS. J.M.E , 2 (2), 215-230.

Putri, R. I. (2011). Professional Development of Mathematics Primary School Teacher in Indonesia Using Lesson Study and Realistic Mathematics Education Approach. Lymasol, Cyprus: Proceeding of International Congress for school Effectiveness and Improvement (ICSEI).

Putri, R. I. (2013). Evaluasi program pelatihan pendidikan matematika realistik indonesia (PMRI) bagi guru matematika Sumatera Selatan. Diseminarkan pada Seminar Nasional Implementasi Kurikulum 2013. Palembang.

Putri, R. I., Dolk, M., \& Zulkardi. (2015). Professional Development of PMRI Teachers for Introducing Social Norms. Journal on Mathematics Education (IndoMs-JME), 11-19.

Retnawati, H., Kartowagiran, B., Arlinwibowo, J., \& Sulistyaningsih, E. (2017). Why are the Mathematics national Examination Items Difficult and What Is Teachers' Strategy to Overcome It? International Journal of Instruction , 10 (3), 257-276.

Sembiring, R. K. (2010). Pendidikan Matematika Realistik Indonesia (PMRI): Perkembangan dan Tantangannya. Indo MS. J. M. E. , 11.

Sembiring, R. K., Hadi, S., \& Dolk, M. (2008). Reforming mathematics learning in Indonesian classrooms through RME. ZDM Mathematics Education , 927-939.

Simon, M. A. (1995). Reconstucting Mathematics Pedagogy from A Contructivist. Journal for Research in Mathematics Education , 114-145.

Standiford, S. N., Klein, M. F., \& Tatsuoka, K. K. (1982). Decimal Fraction Arithmetic: Logical Error Analysis and Its Validation.

Wijaya, A. (2012). Pendidikan Matematika: Suatu Alternatif Pendekatan Pembelajaran Matematika. Yogyakarta: Graha Ilmu.

Zulkardi, \& Putri, R. I. (2010). Pengembangan blog support untuk membantu siswa dan guru matematika Indonesia belajar pendidikan matematika realistic Indonesia (PMRI). Jurnal Inovasi Perekayasa Pendidikan (JIPP) , 2 (1), 1-24.

Zulkardi. (2002). Developing a Learning Environment on Realistic Mathematics Education for Indonesian Student Teacher. Netherlands: University of Twente, Enschede. 